\title{
Government procurement clause in EVFTA and implications for Vietnam
}

\author{
Nguyen Tien Hoang ${ }^{*}$, Do Hoang Vuong
}

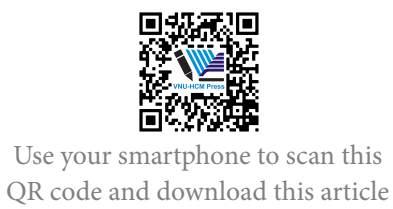

Foreign Trade University, Vietnam

Correspondence

Nguyen Tien Hoang, Foreign Trade University, Vietnam

Email: nguyentienhoang.cs2@ftu.edu.vn

History

- Received: 03-9-2020

- Accepted: 02-11-2020

- Published: 09-11-2020

DOI : 10.32508/stdjelm.v4i4.693

\section{Check for updates}

Copyright

( ) VNU-HCM Press. This is an openaccess article distributed under the terms of the Creative Commons Attribution 4.0 International license.

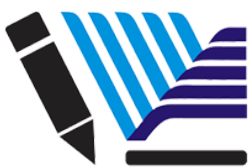

VNU-HCM Press

\begin{abstract}
EVFTA is one of the newest endeavors of Vietnam regarding the international integration process, which is anticipated to be beneficial for Vietnam in many aspects across industries. The government procurement sector does not stay out of this influence. This article mainly aims to explore the government procurement sector of Vietnam, the performance of the government regarding managing this market and how it will be affected and reformed by EVFTA. More importantly, by examining the significant factors that may have an impact on the EVFTA's implementation from Vietnam's perspective, the article attempts to assess the compatibility of the current situation of Vietnam with the fundamental conditions to conduct public procurement regulations of EVFTA efficiently. The article collects, summarizes, and analyzes the secondary data from trustworthy sources like the Vietnam General Statistics Office, the ranking table of the International Telecommunication Union, the official annual report of state departments of Vietnam, and other documents like journal articles, research papers,etc. Another methodology employed in the research is the in-depth interviews with professional experts who have been working for several years in the international integration field. the article discovers that Vietnam is capable of implementing EVFTA's chapter 9 efficiently but with more careful preparation. The article also points out that despite of having a strong mindset of globalization, Vietnam's public expenditures are still loosely covered by laws, which leads to irrational allocation on national budget. A number of implications are suggested to localize the EVFTA's regulations and recommendations are made to apply modern technologies to improve the procurement system, especially on the capacity of government on managing the government procurement sector. The authors hope to help state authorities to have a broader look and improve the sector as well as embrace the opportunities from EVFTA regarding government procurement sector.
\end{abstract}

Key words: EVFTA, government procurement, implications, Vietnam

\section{INTRODUCTION}

The modern world has witnessed rapid growth in the economy and the living standard of people around the world over a few decades. In this progress, many associations, agreements, policies have been established and gathered many members into building mutual prosperity. Vietnam is not an exception in this global tendency. Vietnam, since the economic renovation in 1986, had realized these opportunities and made great efforts to integrate into the global economy and at the end of the year 2019, several bilateral and multilateral agreements on global co-operation have been signed and conducted, especially the ones with in-depth and comprehensive coverage across many aspects of the members' economy.

EVFTA, the latest "new-generation" agreement that Vietnam concluded, is expected to bring many changes, both opportunities, and challenges to the national economic development, including the operation of the Vietnamese government and its depart- ment, in which government procurement is an important field. The total actual budget for Vietnam government procurement has been maintained at a high level, approximately $39 \%$ of the national GDP, one of the highest numbers in the world. Along with the rapid growth of government spending, Law No. 43/2013/QH13 on Bidding (VNLB) was legislated and published in 2013 to regulate the buying relationship between national departments and the suppliers of goods and services. This Law and its by-law documents have managed the domestic government procurement with stability over the recent years. However, compared to EVFTA, VNLB still has several differences in terms of regulating the industry.

These differences raised numerous issues to Vietnam as Vietnam will be standing between the regulations of EVFTA and the local ones on the government procurement sector. After a period of time doing research, it is found out that there was numerous research on government procurement clauses in FTAs 
in general, on the government procurement problem that EVFTA covers, and on the current situation of Vietnam regarding the government procurement sector but not on these clauses' impact on Vietnam and further, how can Vietnam take advantage from this free trade agreement to improve the public procurement market to develop the country. Moreover, almost all clauses will be in force in the near future, which means this is an urgent and important problem to be announced and researched on. Therefore, the authors choose this issue as the topic of this article.

\section{LITERATURE REVIEW}

\section{Regarding the government procurement clause in Free Trade Agreements (FTAs)}

Jean Grier (2006), Recent Developments in International Trade Agreements Covering Government Procurement. In this article, the authors cleared that the GPA is the model construction for the regulations on government procurement in FTAs and any FTA that the US ever signed with other countries covered this sector, set an example for the FTAs around the world, however, did not concern the actual politics and economics between partners in these FTAs ${ }^{1}$.

Steve Woolcock (2013), Policy diffusion in public procurement: the role of free trade agreements. The authors investigated the relationships between free trade agreements and its member states' law system on government procurement and clarified that free trade agreements contribute to the stipulation of policies and regimes of the member nations on government procurement. The drawback of the research was the lack of consideration of the differences and collisions between these law systems and the solutions for that issue. The drawback of the research was the lack of consideration of the differences and collisions between these law systems and the solutions for that issue $^{2}$.

Ranja Sengupta (2012), Government procurement in the EU-India FTA: Dangers for India. In this article, the authors defined this as the key tool to develop the country and indicated the risks of losing control over this key tool when adding the regulations on government procurement into free trade agreements and hence losing the ability to orientate the socioeconomy. On the other side, the potentials and solutions to prevent similar issues to happen were rarely investigated and analyzed ${ }^{3}$.

Regarding the government procurement clause in EVFTA

Nguyen Thi Thu Trang (2016), Rà soát pháp luật Việt Nam với các cam kết của Hiệp dịnh thương mại tự do
Việt Nam - EU về Mua sắm công. In this document, the authors compared the government procurement clause in EVFTA and Vietnam's current legal system to point out the compatibility and emphasize the regulations need to be modified. The law used in this research is Vietnam Law No. 43/2013/QH13 on Bidding (VNLB). Despite the clear structure of the analysis, the research only focused on the legal side of the comparison while economic and political aspects are important as well ${ }^{4}$.

Nguyen Dinh Cung et al. (2017), Hiệp dịnh thiơng mại tư do Việt Nam - EU: Tác động thể chế và điêu chinh chính sách ở Việt Nam. This research document focused on the overall impacts of EVFTA on Vietnam. It examined groups of regulations in EVFTA and then analyzed both quantitatively and qualitatively to derive several implications for Vietnam to be in the best circumstances for implementing EVFTA's stipulations. Due to the wide range of research, the government procurement sector was mentioned in a short part, which cannot cover the sector sufficiently ${ }^{5}$.

Bernhard Tröster et al. (2019), Combining trade and sustainability? The Free Trade Agreement between the EU and Vietnam. The research report combined the analysis of numerous clauses of EVFTA related to sustainable development and concluded that even though containing many potential benefits, EVFTA was still a challenge for Vietnam in terms of implementation. However, the government procurement was not focused on the research ${ }^{6}$.

Rabea Brauer, Vu Dang Tuan, and Natalie Frey (2014), Free trade agreement between the EU and Vietnam: difficult partnership. With a skeptical viewpoint, the authors analyzed the current political institution and environment and judged that the role of the Vietnam government and state-owned enterprises in the market is dominant and may pose inadequacies to the economy. In the range of the analysis, the government procurement was not investigated properly and often, due to the concentration on the political and economic relationship between the two countries ${ }^{7}$.

\section{Regarding the government procurement sec- tor in Vietnam}

Chu Thi Thuy Chung (2016), Mua sắm công ở Việt Nam: Thực trang và giải pháp. The research paper showed the results of the implementation of Vietnam Law No.43/2013/QH13 on Bidding after three years of operation, both optimistic and pessimistic aspects. Numerous solutions to improve the efficiency of the government procurement market in Vietnam were proposed as the current situation is not efficient. Not 
mentioning the impact of FTAs that Vietnam joined, the research only gave readers references on the domestic market, not the international one ${ }^{8}$.

Baker, Paul et al. (2014), Sustainable impact assessment EU-Vietnam FTA. In this research, the authors analyzed the impact of EVFTA on Vietnam regarding sustainable development, including the government procurement. It is predicted that local preference policies in this sector like Vietnam can lead to the "inefficiency and corruption". The research, on the other hand, did not cover the analysis of inefficiency and corruption, as well as factors affecting the EVFTA implementation of Vietnam ${ }^{9}$.

Do Kien Vong (2019), Quản lý nhà nước về đấu thâu mua sắm công ở Việt Nam. In this doctoral thesis, the authors investigated the current management system of tendering activities in Vietnam between government authorities and suppliers. There was also a chapter mentioning systemized solutions to promote efficiency and transparency in this activity of Vietnam. Nevertheless, none of the contents mentioned the potentials of this sector under the cooperation with foreign countries ${ }^{10}$.

Tran Thi Dong Anh (2009), Pháp luật về đấu thâu điện tử của một số nước, kinh nghiệm và khả năng áp dưng ở Việt Nam. The document investigated the experience of countries around the world regarding e-procurement and then analyzed the compatibility to apply in Vietnam via the evaluation of the current tendering management system. The authors concluded that even though the e-procurement is very potential, there shall be challenges that require high efforts to overcome. As stated in the subject, the research did not pay enough attention to other issues but e-procurement, which means the context of e-procurement was not comprehensively investigated $^{11}$.

$\mathrm{Vu}$ Thi Hien (2017), Việt Nam huoớng tới tham gia Hiệp định mua sắm chính phủ (GPA) của WTO: nhũng thách thức tù góc độ minh bạch hóa. The authors in this article examined the ability of Vietnam to join GPA by comparing the current management system and the standards of the World Trade Organization (WTO). The main principle analyzed in this article is transparency, which is also one important rule in EVFTA. However, many other essential aspects such as the rule of fairness, etc. were not included in this research ${ }^{12}$.

None of the above research analyzed and showed the big picture of how the regulations of EVFTA on the government procurement shall influence Vietnam and what the possible measures to take advantage of
EVFTA on the foundation of Vietnam's current performance in this sector are. These are the expected outcomes that the article provides.

\section{METHODOLOGY}

The research method used in the article is mainly Qualitative and Descriptive. The article collects, summarizes, and analyzes the data from two sources:

Secondary data: The article summarizes the data taken from various trustworthy sources: ranking table of International Telecommunication Union; data collected by the General Statistics Office of Vietnam; and reports from the Ministry of Finance and Ministry of Planning and Investment. The article also uses the information from the trustworthy sources, namely books, newspapers, magazines, legal articles, reports, and research papers in Vietnam and the world.

In-depth interview: The article collects the consultancy from (1) Dr. Pham Van Chat, Senior Lecturer of Ministry of Industry and Trade on international economic integration, and (2) MSc. Pham Binh An, Director of the Ho Chi Minh City Centre of International Integration Support. The two experts above are the experienced professionals in issues related to the international integration process of Vietnam.

\section{RESULTS AND FINDINGS}

\section{EVFTA and the Government procurement clause in EVFTA}

Vietnam and the European Union first established diplomatic relations on November $28^{\text {th }} 1990$. Before 2000, in 1992, 1995, 1997, three mutualbenefit agreements was adopted, “Textile Agreement", "Vietnam-EC Cooperation Framework Agreement" and "ASEAN-EU Cooperation Agreement" respectively have improved the opportunities for both governments in an effort to develop the economy, stabilize the political institution and construct better strategies to effectively integrate to the international environment. After 2000, numerous events were held to enhance this trade relation. The most remarkable milestone under this endeavor is the initiation of EVFTA negotiation in 2012. And EVFTA is considered the most comprehensive bilateral agreement that Vietnam has ever concluded.

On December $1^{\text {st }}$, 2015, the EU and Vietnam officially announced that the negotiation course was concluded after a long way of negotiations with 13 official rounds. On those foundations, February $1^{s t}, 2016$, the text of EVFTA was publicly accessible on the official website of the Directorate-General For Trade. Both parties agreed with the full text of EVFTA and EVIPA 
and officially signed on June $30^{t h}, 2019$. The ceremony of signing the agreement became the next big milestone in the trade relation between EU and Vietnam as well as an opening stage for them to go faster into the global economic integration. On February $12^{\text {th }}, 2020$, the European Parliament give consent (63.33\% voting for consent) to EVFTA. The main contents of EVFTA covered many aspects in the trade relation of the two states including tariff elimination under a preferential schedule, rules of origin, procedural simplification and transparency, buyers protecting, and sustainable development. All of these chapters in EVFTA mainly aim to promote transparency, fair competitiveness, and to create an ideal business environment for companies from the EU and Vietnam. It also gives Vietnam a great chance to expand the business with the world, to reduce social issues like unemployment, to revise the current politics and institution if necessary.

Most of the regulations on the government procurement in EVFTA are derived and based on the text of GPA (1984) because GPA is the biggest agreement on this sector regarding the number of members. The principles of chapter 9 in the government procurement in EVFTA can be illustrated as follows:

Firstly, the transparency principle: under this chapter, transparency is regulated to guide both countries' government in constructing an exclusive system of information which is freely accessible to domestic firms as well as foreign firms, an electronic mean is highly recommended. In this system, the information of the contract has to be sufficiently clear, especially prices, terms, and conditions. However, EVFTA created a roadmap for Vietnam to exempt this clause for 10 years after the validation of the agreement to fully prepare for the implementation duty.

Secondly, non-discrimination treatment: EU and Vietnam aimed to form a fairly competitive market for firms of both sides to do business in, and fair treatment is vital to build such an ambitious environment. EVFTA also requires that all purchases must be open tendered except for the contracts that meet conditions to hold limited or selective tendering.

Thirdly, electronic tendering: electronic tendering is one of the newest means of tendering in the world to increase the efficiency of the government procurement tendering process. EVFTA also includes this element to enhance the speed and fairness in the sector. Fourthly, anti-fraud: both parties under EVFTA have to make a legal framework to settle disputes fairly and effectively.
Factors affecting the implementation of the government procurement clause in EVFTA from Vietnam perspective

To analyze the factors affecting the implementation of EVFTA's chapter 9, it is crucial to investigate the previous research on the indicators of efficiency in tendering activities management. Ngugi \& Mugo (2012) investigated the impacts on Kenya's government procurement sector of 4 internal factors: "accountability" of authority bodies in conducting government procurement activities; "information communications technology adoption" (ICT adoption); “internal process" which relates to the legal framework that manages contractors and contracts in this activity; and "ethics". The 4 factors mentioned above explained for $82.5 \%$ of the procurement process efficiency ${ }^{13}$. Kiage (2013) collected more affecting variables in his research, which are 4 main big factors: "procurement planning"; "resources allocation"; "staff competency"; and "contracts managements". In his findings, these 4 factors explain about $87.5 \%$ of procuring performance $^{14}$.

Kiama (2014) insisted after analyzing the quantitative research that "Strategic planning", "Regulation enforcement" and "Organization culture" are the three determinants of the government procurement performance ${ }^{15}$, which partially agrees with the research mentioned above. Paying most of the attention to legal framework and ethics, Amayi \& Ngugi (2013) took a correlation test and found out that "legal framework", "information communications technology" (ICT) and "ethics" can deeply explain for variations of the government procurement efficiency ${ }^{16}$.

In Vietnam, Do Kien Vong (2019) in his research, pointed out that there are 5 factors having impacts on the government procurement performance which are: "legal environment"; "means and types of tendering"; "contract's commodity and features"; "management capacity"; and "international integration spirits" 10.

As for the consideration about the above results and the actual characteristics of Vietnam economy, the article chooses to analyze 5 factors which relate the most to Vietnam: (1) existing legal framework (or environment), (2) contracts management capacity, (3) procurement planning activity, (4) ICT adoption and (5) international integration spirits.

\section{Existing legal framework}

In Vietnam, "procurement rules have for years not only been limited in scope but have also been highly fragmented" 17 . The current law stipulating the tendering activities is the Law No.43/2013/QH13 on Bidding (VNLB). Compared to the earlier versions of 
laws regulating this sector, this law is superior, more sufficient, and closer to the global standards. Before 2005, this market in Vietnam is mainly the playground for the state-owned enterprises and regulated by Decision No. 24/BXD-VKT on Mechanism of bidding for construction contracts on February $12^{\text {th }}$, 1990, and its following modifications. After a long time of inefficient operation with many drawbacks, Law No. 61/2005/QH11 on Bidding on November $29^{\text {th }}, 2005$ was issued as the first law-level legal document created a framework to ensure the efficiency of government procurement procedures. With the range of governance as an official law, Law on Bidding 2005 has arranged the functions relatively rationally. The bidding process was regulated, much or little, in many legal documents which caused the overlaps between laws and the inefficiency among departments within the country ${ }^{17}$. For example, "two departments regulating this at the same time are Ministry of Finance and Ministry of Planning and Investment" ${ }^{8}$. The latest version of the law on the public procurement, as illustrated in the previous section, is the law made from the resources of GPA's principles. As a consequence, issued on November $26^{t h}, 2013$, the VNLB made a wind of change to the sector in Vietnam. With the issuance of Decrees and Circulars following them to instruct the implementation of the Law, this new legal system has reached several positive objectives. Firstly, the standardization of procuring procedures eliminated most of the biased information from other laws or by-law documents. Moreover, the law expands the chances for firms by reducing contracts bid by direct appointments. This expansion enhanced the competitiveness of the government procurement market as firms can participate in the bidding process easily. Then, the Decree No.63/2013/NĐ-CP on instructions to the VNLB was issued on June $26^{\text {th }}, 2014$, which clarifies and instructs the specifications for the firm to join the procuring process as well as the information publication mechanism of state authorities. Finally, the electronic procurement is the brightest point among the Law on Bidding of 2013. It can be concluded that the law made a big leap to a better version of the government procurement in Vietnam with higher transparency and openness. However, the domestically preferential policies in the law, in terms of conditions for implementing EVFTA, shall be a significant obstacle due to the conflict with the agreement. Besides minor negative points that need urgent measures, the current legal framework of Vietnam regarding the government procurement sector is relatively progressive. With the implementation of EVFTA, it is predicted to create several expansions to regulate this foreign-involved activity.

\section{Contracts management capacity}

With tendering processes and procedures, Vietnam is running this market with a system relatively close to international standards; the average time to proceed with a procurement package is about 183-215 days while this number in member states of GPA is $85-382$ days ${ }^{18}$, nearly the same median. The drawbacks here lie in the actual operation as several negative points show up. For example, bid rigging is a form of corruption that official(s) in the state authorities give privileges and irrationally preferential advantages to certain suppliers to exchange for benefits. The information established about the procurement plans under the current situation, however, is considered as a progressive step when it is easily accessible through many channels.

Regarding the quality of human resources in the government procurement sector, Duong Xuan Ngoc (2019) insisted that the quality of public employees has been improved steadily in recent years. He also analyzed that the structure of employees within the government has a positive change in the upward trend of high-qualified workers ${ }^{19}$. At the end of 2012, there are a total of 535,528 public employees in the country with $56 \%$ of them had at least a university degree. He emphasized that many progresses are made to the recruitment process. Law No. 22/2008/QH12 on Public Employees issued on November $13^{\text {th }}, 2008$, Law No. $58 / 2010 / \mathrm{QH} 12$ on State Officials issued on November $15^{\text {th }}, 2010$, and laws on organizing state authorities regulates the rights, obligations, and qualifications of public employees during recruitment. This is a progressive point on the way to improve the working capabilities of human resources in national bodies.

However, Vietnam has a huge quantity of state officials in South East Asia. According to the General Statistics Office's data, until July $1^{\text {st }}$, 2017, Vietnam has 3.8 million state workers, accounting for almost $5 \%$ to the total population, highest in the South East Asia region ${ }^{20}$. Moreover, in Vietnam, a large number of state officials stay in the permanent payroll, which is believed to reduce the motivation to work as well as the efficiency because these public employees feel safe about the stable compensation packages. Therefore, the budget spending on compensation of workers accounts for a big proportion of the total budget, which leads to a dangerous situation if the quality of works is not deserved with that budget. In the first quarter of 2019, according to the report of the Ministry of Finance, the expenditure for employees' compensation consumes $50 \%$ of Normal expenditure account or $31 \%$ of the total national budget in equivalent, about 
500 trillion VND (estimated with data form Plan of national budget 2020) ${ }^{21}$. Last but not least, there exists not only the deficiency in the recruitment process but also the unbalance in the distribution of qualified workers between departments due to the unethical ways to get the job in the state authorities.

It can be judged that the contract management capacity of Vietnam in the current context is relatively under the global standards with many loopholes for corruption, which are quite barriers to adapt to EVFTA's requirements.

\section{Procurement planning of authority depart- ments}

Within Vietnam, procurement planning is an internal activity, which means only the procuring entities can be aware of the tender documentation before it's published to the official tender information channel. Here is the analysis of several aspects of procurement planning activities in Vietnam. In general, the current system is not bright.

Firstly, about delayed tender documents publication (refers to the tender approved but published at least 7 working days later), on average, there are about 45 tender packages have a late publication (calculated by the authors on 2018's data of Dau Thau News) on the tendering information portal each day, which leads to about 11,698 packages with the late publication of information each year accounting for $4.69 \%$ of total procurement packages of the country ${ }^{22}$. This shows the weaknesses in conducting the government procurement planning of the state authorities. Most of the delayed procurement invitations are from local authorities, where the procurement planning are not rational, mostly based on the short-term objectives of officials. Secondly, the regulations of law on procurement planning are not specifically clear. Article 33, 34 in VNLB regulates the necessary information of a procurement plan including superior approvals, budget, quantity, etc. However, the Circular No.10/2015/TT-BKHĐT instructing those 2 articles and the attached Annex 1 didn't mention the objectives, the rationale of the procurement planning. Moreover, Article 24, 25 in Decree No.25/2020/NĐ-CP mentioned broadly on the planning activities in the sector but it's not enough to guide the departments to conduct these activities. Decree No. 63/2014/NĐ-CP doesn't mention the criteria to form a procurement plan. The problem stays at the demand of the departments, where the purpose of procurement can be exaggerated to expand the budget and may cause corruption. Without a reasonable plan of procurement, the state departments shall have difficulties looking for the efficiency in the government procurement sector and hence set up barriers for the implementation of chapter 9 in EVFTA.

\section{Information Communication Technology (ICT) application}

Vietnam is under a modernization process with the awareness of the benefits of the application of the newest technologies to the management activities of the Vietnamese government.

Alghamdi, Goodwin, and Rampersad (2011) set up a framework to assess the readiness of a developing country on applying e-government which contains a number of criteria ${ }^{23}$. The Table 1 shows the analysis of Vietnam's current ICT adoption.

Vietnam is on the way to form the platform of egovernment, however, through the analysis of the checklist derived from the table above, the ICT application in Vietnam's government is fundamentally not qualified enough, especially the government secure network, ICT architecture, and infrastructure. Regarding internet-based security activities, in 2019, the internet criminals robbed 20,892 billion VND from Vietnam's citizens, increased by 5,992 billion VND compared to $2018^{24}$. Vietnam's ICT Development Index in 2017 is 4.43 points, ranking 108 globally, which is relatively worse than the global average ${ }^{25}$. The architecture of ICT in Vietnam's government procurement, even though has many progressive steps forward, there are still several technical deficiencies in the tendering ICT. Regarding ICT infrastructure, the stability of this system, as well as that of general internet connection of the nation is not good. In recent years, there are numerous troubles happening to the optical fiber cable system connected to the world internet. The same risks can happen to tender sessions as firms lose the chances to apply for a bid and hence decrease the fairness.

Overall, the ICT adoption of Vietnam regarding the government procurement sector reveals numerous weaknesses that need amendment however, the fastgrowing speed of ICT systems across the country proves the development potential in the near future.

\section{International integration spirits}

From 1991, after 5 years of renovating the country, Vietnam's government orientates the integration policies as "multilateral and diversifying diplomatic relations". Since then, the determination of the Vietnamese government is bigger to join the global economy. In 1996, the Resolution No.01-NQ/TW stated to "accelerate the process of international integration". In 2011, at the Eleventh National Congress 


\section{Table 1: Checklist on the ICT development of Vietnam regarding public procurement}

\begin{tabular}{|c|c|c|}
\hline No. & Criteria & Brief Assessment \\
\hline 1 & $\begin{array}{l}\text { General ICT appli- } \\
\text { cation strategy }\end{array}$ & $\begin{array}{l}\text { Well conducted by the Vietnamese government with laws, decrees, and circulars. In } \\
\text { many fields of socio-economy like education, legal procedures, medication, it is highly } \\
\text { recommended by the state authority to apply with new technology. Moreover, the trend } \\
\text { to combine and utilize the decentralized contents from collaborating authority entities } \\
\text { is very obvious in recent years. }\end{array}$ \\
\hline 2 & System’s User Access & $\begin{array}{l}\text { Firms and citizens can supervise by free access to the information portal, however, } \\
\text { within a limitation. The information which is supposed to come to the firms and cit- } \\
\text { izens are friendly approaching. Almost departments, ministries, offices, agents, insti- } \\
\text { tutes now established their independent websites for updating information of the or- } \\
\text { ganizations and keep in touch with the stakeholders. }\end{array}$ \\
\hline 3 & \multicolumn{2}{|c|}{ E-government programs } \\
\hline 3.1 & $\begin{array}{l}\text { Single-Sign-On Pro- } \\
\text { gram }^{*}\end{array}$ & $\begin{array}{l}\text { Not yet applied to the system even though this type of innovation is widely used in } \\
\text { developed countries like Singapore, Australia, United States, etc. }\end{array}$ \\
\hline 3.2 & $\begin{array}{l}\text { Government Service } \\
\text { Bus }\end{array}$ & $\begin{array}{l}\text { Applied but still bulky, not lean, and mostly top-down structure, especially in terms of } \\
\text { information transition. The cooperation between related departments is still loose so } \\
\text { the co-efficiency is not promoted after a few years of application. }\end{array}$ \\
\hline 3.3 & $\begin{array}{l}\text { Government Secure } \\
\text { Network }\end{array}$ & No specialized department in charge even though there is a law on this issue \\
\hline 4 & ICT Architecture & $\begin{array}{l}\text { Not efficient, there are portals in the Ministry of Planning and Investment as well as } \\
\text { Dau Thau News and the government procurement portal; scalability and stability are } \\
\text { not well-designed }\end{array}$ \\
\hline 5 & $\begin{array}{l}\text { Business process } \\
\text { and information } \\
\text { systems }\end{array}$ & $\begin{array}{l}\text { The tendering process is relatively close to the international standards but the system } \\
\text { to exchange the information within and between state authorities is not good enough. }\end{array}$ \\
\hline 6 & ICT Infrastructure & $\begin{array}{l}\text { Vietnam is one of the fastest-growing countries regarding ICT devices and the usage of } \\
\text { citizens. The infrastructure, by that, developed fast in recent years }\end{array}$ \\
\hline
\end{tabular}

Source: analyzed by the authors from the framework of Alghamdi, Goodwin, and Rampersad (2011)

of the Communist Party of Vietnam, the orientation of "proactively integrate with international" was first introduced, and through the Resolution 22-NQ/TW, global integration has become the central direction in economic development of the country. It's undeniable that there has been a great deal of progress made by Vietnam due to the reasonable strategies and orientations of the Party and the Vietnamese government ${ }^{26}$. Until March 2019, there are total 13 bilateral and multilateral free trade agreement has been signed including the most comprehensive agreements: EVFTA and CPTPP.

This factor is one of the strongest points in Vietnam. Since Vietnam is eager to cooperate and locate opportunities from EVFTA on the global economic collaboration path, it can highly adapt to the regulations of EVFTA on the government procurement.

\section{DISCUSSION AND CONCLUSION}

\section{Discussion}

\section{Current situation of Vietnam regarding the government procurement}

The period of 2013 - 2018 witnessed the total value of the government procurement tendered rocketed by about 1.5 times from 411 trillion VND to 647 trillion VND. This value always accounts for around $10 \%$ of GDP annually ${ }^{27}$. The explanation for this increase is that Vietnam, with the expansion of the economy and trade with other countries in the world, needs to have a better controlling system to manage or fund the development of the society. However, the efficiency of the tendering process has not been ignored; it increased well with the savings from the government procurement tendering procedures. According to $\mathrm{Mr}$. Pham Binh An, this tendering activities in Vietnam are still facing the constraint between the quality and time in the tender packages with specialized contents or with limited participants. If all the administrative 
procedures are performed sufficiently, it will take a long period of time, which is wasted. On the other hand, if any step in the procedures is skipped, the contractors are hardly rewarded with the contract. Besides, with the current management capacities of Vietnam regarding the government procurement, many frauds caused by the bid rigging can happen ${ }^{\mathrm{a}}$. This is the dark side of the current tendering system, which can cause unnecessary wasted resources. It is urgent that the Vietnamese government needs to make great determination and endeavors to intervene and improve the system of tendering.

\section{Implications for Vietnam state authorities}

Firstly, regarding the legal framework, Vietnam should clarify and modify the definitions system in the government procurement field. Most of the definitions of these two legal documents are equivalent; however, some definitions may cause misunderstanding like "direct appointment" under Vietnam law and "limited tendering" under EVFTA, should be clarified for firms, both domestic and foreign. This measure also prevents the conflicts of regulations in the future. According to Mr. Pham Binh An, the most important thing to successfully launch this agreement is that Vietnam has to "localize" the contents of the EVFTA to create compatibility with the current socio-economy of Vietnam. This process includes checking and comparing EVFTA's regulations with Vietnam's law and adjusting the unsuitable clauses to apply the agreement to Vietnam. ${ }^{\text {b }}$ Mr. Pham Van Chat has the same opinion about this problem insisting that the Vietnamese government is standing in front of the demand of modifying the legal environment, conditions, and procedures in the related law and by-law documents, taking advantage of the modern technologies to conduct the regulations as well as possible. ${ }^{c}$ The best way to "localize" these contents is that to form separate legal documents to ensure the implementation of EVFTA's government procurement clause in Vietnam [ ${ }^{4}$, p.30]. This measure is reasonable because the costs to entirely change the existing legal framework is too high; besides, the regulations of the VNLB are very closed to the international standards, and their differences compared to EVFTA are only specifically applied to the government procurement relation between the two countries; and the

\footnotetext{
a Pham Binh An (Mr) - Director, Hochiminh City Centre of International Integration Support (CIIS).

${ }^{\mathrm{b}}$ See supra note 1

${ }^{c}$ Pham Van Chat (Mr) - Arbitrator, Vietnam International Arbitration Center; Senior Lecturer on International Economic Integration, Ministry of Trade and Industry.
}

later inspection and review may be easily conducted due to the clarity. And it is hard to deny that the treatment to frauds should be more strict and serious to prevent and punish the criminal behaviors. The experiences from Russia after the collapse of the Soviet Union show that heavy punishments are highly effective in enhancing this sector ${ }^{28}$.

Secondly, regarding the management capacities towards the government procurement sector, it is necessary to have a system to assess the quality of the contracts' performance with contract justification and a clear frame of specifications. This activity should be carried out by an independent authority organization. Without inspecting the quality of the procurement contracts, frauds and deficiencies may occur and cause negative results for the development plan. In Vietnam, investigating after contracts is a loose and shaky step. In recent years, many constructions are detected to be distorted from the requirements, and only when accidents happened did the people know about the frauds. Setting clear specifications and checking carefully after contracts are carried out are contributing to the efficiency of the whole government procurement sector, especially in EVFTA. Another applicable stipulation is multi-use lists, an effective measure to save the costs of holding dispersive bidding sessions because the Vietnamese government hasn't systemized the common needs of departments so as a consequence, the costs of holding separate bidding sessions by each authority for the same commodity will cause overlap and be unreasonably wasted. EVFTA cleared that this regulation is optional, and Vietnam can be very beneficial to make use of this mechanism. For years, legal procedures have been a heavy burden for any company working in Vietnam. It used to take a long time and several steps to proceed with a document, permission, a certificate, etc. It is suggested that Vietnam should build a system of "one door process" which means the citizens only come to the state authority for once and then their needs are fulfilled. These citizens shall be guided to complete the information, fulfill the essential documents, and once done, they will wait for the next appointment to have the problems solved. This measure requires a high infrastructure of ICT and smart design of procedural systems like the database; the applications to guide citizens prepare the documents from home to save time, the digital signatures to decrease the time of waiting for approvals, etc. Last but not least, redesigning the recruitment process makes the administrative activities more efficient. The drastic measures include eradicating the guan$x i$ culture - taking jobs and benefits by relationships 
with powerful people; adding the third-party supervision in the recruitment process; and raising the basic compensation packages so that employees can focus more on the job rather than looking around the opportunities to do additional jobs at the same time and cause a decline in the main work efficiency. These actions only solve the short-term problems; to develop talents in the long-term, the government should improve the education system, especially the career orientation and job training. With the current situation of Vietnam, these measures should be performed gradually through careful steps due to the existence of many benefit groups. However, with the determination of the Party, it is highly believed that the efficiency of the state authorities shall be developed in the near future.

Thirdly, regarding the ICT application, from the checklist of Alghamdi, Goodwin, and Rampersad ${ }^{23}$, to successfully implement the government procurement clause under EVFTA, it is critical for the Vietnamese government to improve immediately these four aspects: ICT infrastructure, ICT architecture, business process with an information system and egovernment programs. To improve these aspects, there is an urgent need of constructing the unique information system of the government procurement shared by state authorities to connect the workflows and increase the efficiency in cooperation between departments in proceeding documentations. This system can be delegated to a third-party unit like Viettel, a world-class state-owned corporate, to construct and give the administrative rights back to the government. With a system like this, the speed of tendering procedures shall be dramatically decreased and facilitate businesses. Moreover, it is crucial to improve the protocol between state authorities and citizens as well as firms. The best scenario is that with one time logging into the system, the citizens and enterprises can access through many procedures and decrease the time of waiting. Not only in the e-tendering process but also in the remaining sectors of the government. Besides, the necessary information for citizens also transported through this protocol, not to mention a feedback mailbox where citizens can suggest measures to improve the current procedures.

Fourthly, regarding the procurement planning activities, there should be accessible measures to resolve the problems of the rationality of the procurement plans: these plans need to be announced to the citizens about its rationality, except for the confidential ones which relate to national security. Moreover, the purposes and the importance of the procurement packages, to be efficient, also need to be justified by another independent specialized authority. Objective judgments from a third-party are always the ultimate reference source to create transparency in any industries and activities. With the surveillance from citizens and the inspection of other departments, the performance of planning activities may be improved. The more transparent these activities are, the more efficient the plans are and the less wasted budget shall be. Finally, regarding the international integration spirits, Vietnam should take advantage of this while making effort not to be ignorant and to be highly progressive and adaptive. Since the beginning of the new $2^{\text {nd }}$ millennium, Vietnam has witnessed numerous frauds and misbehaviors of foreign companies with their Vietnamese partners ${ }^{29,30}$. The ignorance of international business customs and laws of Vietnam firms is partially to blame for these unfortunate events. The solutions are clear: the government should frequently update the knowledge about the international business environment and legal aspects to help domestic firms avoid the common mistakes and gradually get used to the regulations of free trade agreements such as EVFTA. Then, they should collaborate efficiently with the foreign government and local Embassy to jointly prevent similar cases to happen in the future. Besides, the outstanding companies that thrive from doing business with foreign partners should be honored by the government to encourage more and more businesses to form their global sales network.

\section{Conclusions}

The above analysis investigated the factors affecting Vietnam significantly while implementing the government procurement clause under EVFTA. Combining with an overview of the current situation of the Vietnam domestic government procurement market, the article presented a number of implications for Vietnam to successfully take advantage of EVFTA's chapter 9 .

These implications are hopefully about to help the Vietnamese government can set up a clear strategy and specific action plan to foresee the potential and take benefits from the government procurement regulations of EVFTA and prevent the negative phenomenon which may occur during the implementation. Furthermore, in compliance with this strategy, the Vietnamese government can improve the sector not only in the relationship with EU's contractors but also the general procurement system in Vietnam, in which the budget distribution can significantly decide the development of the country. 
Despite the intense effort of the Authors, the article is not able to cover the entire picture of the government procurement reality of Vietnam compared to the global standards as long as the quantitative impact of chapter 9 of EVFTA on the Vietnamese market. These are potential orientations for further research./.

\section{LIST OF ABBREVIATIONS}

EVFTA: EU - Vietnam Free Trade Agreement ICT: Information communication technology

VNLB: Vietnam Law No. 43/2013/QH13 on Bidding CPTPP: Comprehensive and Progressive Agreement for Trans-Pacific Partnership

GPA: Government Procurement Agreement

GDP: Gross domestic product

FTA: Free Trade Agreement

WTO: World Trade Organization

\section{CONFLICTS OF INTEREST}

The authors declare that there are not any conflicts of interest.

\section{AUTHORS' CONTRIBUTIONS}

The authors have equally contributed to the article.

\section{REFERENCES}

1. Grier J. Recent Developments in International Trade Agreements Covering Government Procurement. Public Contract Law Journal. 2006;35(3):385-407.

2. Woolcock S. Policy diffusion in public procurement: The role of free trade agreements. International Negotiations Journal. 2013;18(1):153-173. Available from: https://doi.org/10.1163/ 15718069-12341248.

3. Sengupta R. Government procurement in the EU-India FTA: Dangers for India. Economic and Political Weekly. 2012;47(28):19-22.

4. Trang NTT. Revision of Vietnamese laws accroding to the committments under the EVFTA on public procurement. Hanoi: Industry \& Trade Publisher. 2016;

5. Cung ND, Thang TT, et al. The EVFTA: Institutional impacts and Policy adjustment in Vietnam. Hanoi: The World Publisher. 2017;

6. Tröster B, Grumiller J, Grohs H, Raza W, Staritz C, von Arnim R. Combining trade and sustainability? The Free Trade Agreement between the EU and Vietnam. Vienna: Austrian Foundation for Development Research. 2019;.

7. Brauer R, Tuan VD, Frey N. Free trade agreement between the EU and Vietnam: difficult partnership. Germany: Konrad Adenauer Stiftung International Reports. 2014;p. 31-47.

8. Chung CTT. Public procurement in Vietnam: Reality and solutions. [Online]. [cited 2020 Mar 21]. 2016;Available from: https://nif.mof.gov.vn/webcenter/portal/vclvcstc/r/ $\mathrm{m} / \mathrm{ncvtd} / \mathrm{ncvtd}$ chitiet?dDocName=MOFUCM084154.

9. Baker P, Vanzetti D, Pham LH. Sustainable impact assessment: EU-Vietnam FTA. Hanoi: MUTRAP IV. 2014;

10. Vong DK. State management on public procurement in Vietnam. Hanoi: Vietnam Academy of Social Sciences. Vietnam National University Library E-Reserve. 2019;.
11. Anh TTD. Law on eletronic bids in some countries: experience and application in Vietnam. Ha Noi National University;.

12. Hien VT. Vietnam is towards the GPA/WTO: challenges from transparency approach. Journal of International Economics and Management. 2017;97(97).

13. Ngugi JK, Mugo HW. Internal factors affecting procurement process of supplies in the public sector; a survey of Kenya government ministries. 5th International Public Procurement Conference. 2012;.

14. Kiage JO. Factors affecting procurement performance: A case of ministry of energy. International journal of business and commerce. 2013;3(1):54-70.

15. Kiama GP. Factors affecting implementation of public procurement act in SACCO societies in Kenya. International Journal of Academic Research in Business and Social Sciences. 2014;4(2):169. Available from: https://doi.org/10.6007/ IJARBSS/v4-i2/614.

16. Amayi FK, Ngugi GK. Determinants of public procurement performance in Kenya: Case Ministry of Environment, Water and Natural Resources. International Journal of Social Sciences and Entrepreneurship. 2013;1(5):647-667.

17. Jones DS. Public Procurement in Southeast Asia: Challenge and Reform. Journal of public procurement. 2007;7(1). Available from: https://doi.org/10.1108/JOPP-07-01-2007-B001.

18. Lent B. International WTO-GPA public tendering - Example Switzerland. 2016;.

19. Ngoc DX. Some issues on state officials (Part 1). Vietnam Central Academy Council Online Journal. 2019;.

20. Vietnam General Statistics Office. Data on population and employment. 2017;Available from: https://www.gso.gov.vn/ default_en.aspx?tabid=774.

21. Vietnam Ministry of Finance. State Budget Estimate. Vietnam Ministry of Finance. 2020;.

22. Dau Thau News. The Late publication of procurement information. 2020;Available from: https://baodauthau.vn/kehoach-lua-chon-nha-thau/.

23. Alghamdi IA, Goodwin R, Rampersad G. A suggested e-government framework for assessing organizational e-readiness in developing countries. International Conference on Informatics Engineering and Information Science. Springer, Berlin, Heidelberg. 2011;Available from: https://doi.org/10.1007/978-3-642-25453-6_41.

24. BKAV. Summary on network security 2019 and forecast 2020. 2020;Available from: https://m.bkav.com.vn/ho_tro_khach_ hang/-/chi_tiet/669034/tong-ket-an-ninh-mang-nam-2019va-du-bao- 2020 .

25. International Telecommunication Union. Information and Communiation Technology Development Index 2017. 2018;Available from: https://www.itu.int/net4/ITU-D/idi/ 2017/index.html.

26. Oanh HTK. Roles of state authorities in Vietnam's active integration into global economy. Hochiminh City: Ho Chi Minh National Academy of Politics. 2016;

27. General Statistics Office. Data on expenditure from national budget. 2019;Available from: https://www.gso.gov.vn/default. aspx?tabid $=715$.

28. Hung TV. Experience of some countries and international organizations in enhancing quality of construction bids. Economic Administration Journal. 2006;8:60-63.

29. Vietnam Ministry of Industry and Trade. Warnings on international commercial transactions. 2017;Available from: http:// www.moit.gov.vn/tin-chi-tiet/-/chi-tiet/canh-bao-lua-\%C4\% 91ao-trong-giao-dich-thuong-mai-quoc-te-108972-401.html.

30. Vietnam International Arbitration Center. Warnings on risks arising from international transactions regarding Echopack Inc. fraud. 2019; Available from: https://www.viac.vn/gocnhin-trong-tai-vien/canh-bao-rui-ro-trong-giao-dich-quocte-tu-vu-lua-dao-cua-echopack-inc-a771.html. 


\title{
Điều khoản mua sắm công trong hiệp định EVFTA và những hàm ý đối với Việt Nam
}

\author{
Nguyễn Tiến Hoàng ${ }^{*}$, Đỗ Hoàng Vương
}

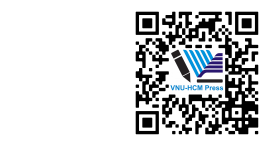

Use your smartphone to scan this QR code and download this article

\section{TÓM TẮT}

EVFTA là một trong những nỗ lực mới nhất của Việt Nam nhằm đẩy mạnh tiến trình hội nhập quốc tế, là khuôn khổ được dự đoán sẽ có lợi cho Việt Nam ở rất nhiều khía cạnh khác nhau. Mua sắm công là lĩnh vực không thể tránh khỏi tác động của Hiệp định này. Mục tiêu của nghiên cứu này là tìm hiểu thị trường mua sắm công ở Việt Nam, hiệu quả của Nhà nước trong việc quản lý thị trường mua sắm công và những tác động của Hiệp định EVFTA đến thị trường này. Quan trọng hơn, thông qua việc xem xét những yếu tố quan trọng có khả năng ảnh hưởng đến việc thực hiện Hiệp định EVFTA từ góc nhìn của Việt Nam, nghiên cứu này đánh giá sự phù hợp giưa thực trạng tại Việt Nam với những điều kiện cơ bản để thực hiện có hiệu quả điều khoản về mua sắm công trong Hiệp định EVFTA. Các tác giả đã thu thập, tổng hợp và phân tích dư liệu thứ cấp từ các nguônn đáng tin cậy như Tổng cục Thống kê, bảng xếp hạng của Hiệp hội Viễn thổng Quốc tế, báo cáo thường niên chính thức của các Bộ, Ban, Ngành ở Việt Nam và các tài liệu khác. Ngoài ra, nhóm tác giả còn sư dụng phương pháp phỏng vấn sâu với các chuyên gia có nhiều năm kinh nghiệm làm việc trong lĩnh vực hội nhập quốc tế. Kết quả nghiên cứu cho thấy rằng Việt Nam có khả năng thực hiện Hiệp định EVFTA hiệu quả nhưng với một sự chuẩn bị kỹ càng hơn. Nghiên cứu cũng chỉ ra rằng mặc dù có quan niệm rất đúng đắn về hội nhập quốc tế, một số khoản chi tiêu của Chính phủ vẫn còn bị quản lý lỏng lẻo, dẫn tới những khoản chi ngân sách chưa hợp lý. Nghiên cứu cũng đưa ra một số hàm ý để nội luật hóa các quy định của EVFTA và một số đề xuất nhằm áp dụng công nghệ hiện đại để cải tiến hệ thống mua sắm công, đặc biệt là năng lực quản lý thị trường mua sắm công của Nhà nước. Nhóm tác giả hy vọng có thể giúp các cơ quan Nhà nước có cái nhìn bao quát hơn và tận dụng những cơ hội mà điểu khoản mua sắm công của Hiệp định EVFTA mang lại.

Từ khoá: EVFTA, mua sắm công, hàm ý, Việt Nam
Trường Đại học Ngoại thuiong, Việt Nam

Liên hệ

Nguyễn Tiến Hoàng, Trường Đại học Ngoại thương, Việt Nam

Email: nguyentienhoang.cs2@ftu.edu.vn

Lịch sử

- Ngày nhận: 03-9-2020

- Ngày chấp nhận: 02-11-2020

- Ngày đăng: 09-11-2020

DOI :10.32508/stdjelm.v4i4.693

\section{Check for updates}

\section{Bản quyền}

๑ ĐHQG Tp.HCM. Đây là bài báo công bố mở được phát hành theo các điều khoản của the Creative Commons Attribution 4.0

International license.

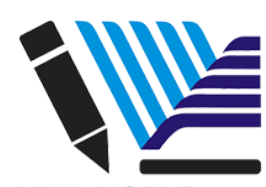

VNU-HCM Press
Trích dẫn bài báo này: Hoàng $\mathrm{N} T$, Vương $\mathrm{D} \mathrm{H}$. Điều khoản mua sắm công trong hiệp định EVFTA và những hàm ý đối với Việt Nam. Sci. Tech. Dev. J. - Eco. Law Manag.; 4(4):1104-1114. 